\title{
Long-term Effect of Residual Zinc and Crop Residues Incorporation on Soil Health and Crop Productivity under Calcareous Soils of Rice-Wheat System in India
}

\author{
Kamini Kumari $^{1}$, J. Prasad ${ }^{1}$, Ishwar Singh Solanki ${ }^{2}$ and Ravish Choudhary ${ }^{2 *}$ \\ ${ }^{1}$ Department of Soil Science, Rajendra Agricultural University (RAU), Pusa-848 125, \\ Samastipur, Bihar, India \\ ${ }^{2}$ Indian Agricultural Research Institute (IARI), Regional Station, Indian Council of Agricultural \\ Research (ICAR) Pusa-848 125, Samastipur, Bihar, India \\ *Corresponding author
}

\section{A B S T R A C T}

Rice-wheat (Oryza sativa L.-Triticum aestivum L.) rotation is the major production system in Asia, covering about 18 million ha. Continuous and conventional RWC system practice has witnessed a significant slowdown in the yield growth rate. The sustainability of this important cropping system is at risk due to second-generation problems (low fertility

\section{Keywords}

Crop residues, Zn, Soil nutrients, Calcareous soil, Yield, Uptake, Rice-wheat.

Article Info

\section{Accepted:}

26 June 2017

Available Online:

10 July 2017 status, multiple nutrient deficiencies, and imbalanced use of fertilizers, ground water depletion at faster rate, soil salinization, and inadequate system diversity). Our results after super-imposition of treatments on an 18-year rice-wheat rotation trial in eastern IndoGangetic plains demonstrated significant effects of crop residues incorporation and $\mathrm{Zn}$ application on soil macro-nutrients, micro-nutrients, their availability, soil chemical productivities and crop productivity. Maximum rice and wheat yields were obtained at $100 \%$ crop residues incorporation along with $10 \mathrm{~kg}$ residual application of starter $\mathrm{Zn} \mathrm{ha}{ }^{-1}$. The crop residue incorporation and $\mathrm{Zn}$ application increased its uptake by $60 \%$ and $57 \%$, respectively. Incorporation of crop residues increased Fe uptake by rice and wheat by $19 \%$ and $39 \%$, respectively. There was an improvement on soil chemical properties ( $\mathrm{pH}$ and OC) with crop residue incorporation. The macro- and micronutrients soil availability also increased with crop residues incorporation, whereas $\mathrm{Zn}$ application reduced $\mathrm{Fe}, \mathrm{Cu}$ and $\mathrm{Mn}$ availability in calcareous soils. The crop residues incorporation can augment micronutrient availability in the calcareous soils. Our results highlight the research need to understand the mechanisms and availability of macro- and micronutrients under different crop residue incorporation levels and micronutrient application in rice-wheat cropping system, which is crucial for developing innovative nutrient application technologies and associated agronomy for higher yield potential.

\section{Introduction}

Rice-wheat cropping (RWC) system is fundamental to South Asia's food security as it plays a leading role in contributing food grains for the region. In India alone, RWC system occupies about $10.5 \mathrm{M}$ ha and contributes about $40 \%$ of the country's total food grain basket (Saharawat et al., 2010). With the adoption of high yielding varieties, higher application of inputs of plant nutrition, irrigation water and improved crop 
management practices, the productivity of RWC system in the region was remarkably increased and had ushered into Green Revolution primarily in North-Western India (Nawaz et al., 2015). However, these gains were accompanied by widespread problems of soil health and resource degradation, which now pose a serious challenge to the continued ability of the region to meet the food demand of an ever-increasing population. Future food production will be limited on a global scale by the availability of land, water, and energy, it will need to successfully address the environmental problems created by current and past agricultural activities, and it must be both adapted to and mitigate against the impacts of climate change (Godfray et al., 2010). In recent years, RWC system has witnessed a significant slowdown in the yield growth rate. The sustainability of this important cropping system is at risk due to second-generation problems (low fertility status, multiple nutrient deficiencies, imbalanced use of fertilizers, ground water depletion at faster rate, soil salinization, and inadequate system diversity). Decoupling future growth from the unsustainable use of fertilizers, nutrients, water, energy, chemicals, and land for increasing food production has become one of the cornerstones for a new sustainable development agenda (Rockstrom et al., 2013; Dobermann et al., 2013). The current approach of RWC production is now known to be ecologically intrusive and economically and environmentally unsustainable which is further aggravated with the fast changing climate in the region.The main reasons for low system productivity even in irrigated areas are the inadequate and imbalanced use of fertilizers in these nutrient exhaustive crops, which have consequently declined the organic carbon and soil health (Yadav et al., 2005).

Hence, for restoration of soil health and productivity, there is an urgent need to look forward to other options like, crop residues incorporation for supplying plant nutrients. The adverse effect of incorporation of rice and wheat straw can be counteracted by integrating organic amendments with crop residues (Singh et al., 2012). The continuous recycling of crop residues restores the organic matter content and also increases microbial population in the soil (Das et al., 2015; Prasad et al., 2010). The RWC system in the next few decades has to be an eco-efficient revolution, with at least $30 \%$ to $50 \%$ increases in the efficiency of scarce inputs as fertilizers and nutrients used while also ensuring the availability of nutritious and safe food for all and minimizing many negative environmental impacts associated with contemporary food systems. Integrated nutrient management is one of the most important components of the agricultural production system to sustain higher crop yields and maintain soil health. The interactive advantages of combining organic and inorganic sources of nutrients in integrated nutrient management have shown additive effects in comparison to the use of each component separately (Das et al., 2012). Systematic studies integrating nutrient management with conservation agriculture (residue incorporation/retention) in the key cropping systems adapted to the changes within and outside of agricultural environment are lacking in the region. Such studies are important for extrapolation to broader geographical levels. Therefore, RWC system production-scale long-term field trial guided by key scenarios of agricultural environment was designed and established in eastern Indo-Gangetic plains of South Asia. In the past, on these aspects, there has been no systematic study in the Eastern IGP, which is home to the world's highest rural population density. As part of this comprehensive study, we report the performance of the long-term effect of residual zinc and crop residues on yield and soil properties under rice-wheat 
cropping system in calcareous soil, a part of the Eastern IGP.

\section{Materials and Methods}

\section{Experimental site}

The field study was conducted on light textured highly calcareous soil deficient in available zinc $\left(0.56 \mathrm{mg} \mathrm{kg}^{-1}\right)$ at the Research Farm of Rajendra Agricultural University, Pusa, Bihar, India (Longitude, 25.9854\% Latitude, $85.6807^{0}$; Altitude, $67 \mathrm{~m}$ above MSL). The field study was established in 1993-94 as a production-scale trial with a long-term perspective involving RWC system. The experimental study was conducted during 2011-12 and 2012-13 as super-imposed treatments in the long-term trial. The climate of study site is sub-tropical humid, with an average annual rainfall of $1130 \mathrm{~mm}$ (85-90\% of which is received from June to September), daily minimum temperature of $7-9^{\circ} \mathrm{C}$ in January, daily maximum temperature of $36-41{ }^{\circ} \mathrm{C}$ in June, and relative humidity of $60-90 \%$ throughout the year. Crop production is distributed across the three seasons that occur in this region: winter (rabi: November-March), summer (April-May), and rainy (kharif: JuneOctober). The summer period is normally fallow period due to water scarcity in the region. The initial soil samples were collected after harvest of the rice crop. Soil samples (0$15 \mathrm{~cm}$ ) were collected from different grids in the plots using anauger of $5 \mathrm{~cm}$ diameter. The soil samples from each grid cell of a plot were composited, air dried, ground to pass through a $2 \mathrm{~mm}$ sieve, and stored in plastic jars until analysis was done. The soil samples were analyzed for $\mathrm{pH}$, electrical conductivity (EC), Organic carbon (Walkley and Black carbon), Olsen $\mathrm{P}\left(0.5 \mathrm{M} \mathrm{NaHCO}_{3}\right.$ extractable $)$, and $1 \mathrm{~N}$ neutral $\mathrm{NH}_{4} \mathrm{OAC}$ extractable $\mathrm{K}$ (by flame emission spectrophotometer). Particle size distribution was determined by the hydrometer method (Bouyoucos, 1962). The textural class was determined by the United States Department of Agriculture (USDA) system. DTPA- extractable micronutrients were determined by an Atomic Absorption Spectrophotometer (Lindsay and Norvell, 1978). The initial soil characteristics of the experimental soil $(0-15 \mathrm{~cm})$ are: $\mathrm{pH}(1: 2) 8.5$, EC $0.36 \mathrm{dSm}^{-1}$, organic carbon $6.2 \mathrm{gkg}^{-1}$, available $\mathrm{N} 236 \mathrm{kgha}^{-1}$, available P $19.7 \mathrm{kgha}^{-1}$, available $\mathrm{K} 100 \mathrm{kgha}^{-1}$, available $\mathrm{Fe} 15.8$ $\mathrm{mgkg}^{-1}$, available $\mathrm{Mn} 3.30 \mathrm{mgkg}^{-1}$ and available $\mathrm{Cu} 2.28 \mathrm{mgkg}^{-1}$.

\section{Experimental details and management}

The experiment was laid out in a split plot design with three replications and plot size of $10 \mathrm{~m}^{2}(5.0 \mathrm{~m} \times 2.0 \mathrm{~m})$. The main plots included different levels of residue incorporation and sub-plots were zinc application levels. The main plot treatment included four levels of crop residues, viz. (T1) -no crop residue $\left(\mathrm{CR}_{0}\right)$, (T2)-25\% of straw produced $\left(\mathrm{CR}_{25}\right)$, (T3)-50 \% of straw produced $\left(\mathrm{CR}_{50}\right)$ and $(\mathrm{T} 4)-100 \%$ of straw produced $\left(\mathrm{CR}_{100}\right)$. The treatments were applied in similar way in each crop every year. The main plot was divided into four subplots in which sub-treatments on zinc application levels, viz. (S1) -no $\mathrm{Zn}\left(\mathrm{Zn}_{0}\right)$, (S2) -2.5 kg Zn ha ${ }^{-1}\left(\mathrm{Zn}_{25}\right)$, (S3) -5.0 $\mathrm{kg} \mathrm{Zn} \mathrm{ha}^{-1}$ $\left(\mathrm{Zn}_{50}\right)$ and $(\mathrm{S} 4)-10.0 \mathrm{~kg} \mathrm{Znha}^{-1}\left(\mathrm{Zn}_{100}\right)$ were superimposed over crop residue levels. These four levels of $\mathrm{Zn}$ were applied only to first crop as a starter dose. The recommended doses of NPK (120:60:40) were applied to each crop of rice and wheat as urea, single superphosphate and muriate of potash. Half of nitrogen and entire dose of $\mathrm{P}$ and $\mathrm{K}$ were applied at the time of transplanting of rice and sowing of wheat and remaining $\mathrm{N}$ fertilizer was applied in the equal splits at tillering and flower initiation stage. Rice and wheat crops were grown continuously under rice-wheat cropping system. Rice cv., Rajshree was 
grown as $33^{\text {rd }}$ and $35^{\text {th }}$ test crop and wheat cv., HD 2733 as $34^{\text {th }}$ and $36^{\text {th }}$ test crop during the reported period of 2011-12 and 2012-13.

\section{Crop harvest and parameter analysis}

At maturity, wheat crop was harvested manually from ground level. The grains were threshed using a plot thresher. Similarly, rice was harvested at the soil surface and threshed manually. Grain and straw yields of both rice and wheat were estimated by manually harvesting a total area of $4 \mathrm{~m}^{2}$ from each plot. Grain moisture was determined at the time of yield estimation using a grain moisture meter. The grain and straw samples were taken at the harvest of rice and wheat crops, and washed sequentially in $0.2 \%$ liquid detergent solution, $0.01 \mathrm{~N} \mathrm{HCl}$ solution and deionized water and dried in oven at $70^{\circ} \mathrm{C}$.

Finely ground samples were digested in a diacid mixture $\left(\mathrm{HNO}_{3}: \mathrm{HClO}_{4} ; 3: 1 \mathrm{v} / \mathrm{v}\right)$ and diluted. Digested samples were analyzed for micronutrients using atomic absorption spectrophotometer. Total uptake of micronutrients by grain and straw was computed. Composite surface $(0-15 \mathrm{~cm})$ soil samples from each plot of the field experiment were collected at the harvest of wheat crop as $36^{\text {th }}$ crop in rice-wheat rotation. Soil samples were air-dried and pulverized to pass through $2 \mathrm{~mm}$ sieve. Available micronutrients were determined by methods described by Lindsay and Norvell (1978). Organic Carbon was determined by rapid titration method as described by Walkley and Black (1934).

Available Nitrogen was determined by alkaline permanganate method (Subbiah and Asija, 1956). Available $\mathrm{P}_{2} \mathrm{O}_{5}$ was determined by Watanable and Olsen's method (1965). Available Potassium was extracted with neutral $1 \mathrm{~N}-\mathrm{NH}_{4} \mathrm{OAc}$ using soil to extractant ratio of 1:5. The potassium in the extract was determined with the help of flame photometer as described by Jackson (1978). The $\mathrm{pH}$ was determined by glass electrode $\mathrm{pH}$ meter (Jackson, 1978).

\section{Data analysis}

Data were subjected to analysis of variance (ANOVA) using the general linear model (GLM) procedures of the Statistical Analysis System Institute (2001). Data were either not transformed or transformed using log, square root, or inverse functions as needed to meet the assumptions of normality and equal variance of population distributions. Scenario mean values were separated by Fisher's protected least significant difference test at $\mathrm{P}<0.05$. The treatment-by-year interaction was significant; therefore, all the data are presented separately for each year.

\section{Results and Discussion}

\section{Crop performance}

\section{Rice crop}

The grain and straw yields of $35^{\text {th }}$ crop of rice as influenced by zinc and continuous application of crop residue at four levels varied from 3.63 to 4.73 and 5.70 to 6.00 tha $^{-}$ 1 , respectively (Table 1). Application of zinc significantly enhanced the mean grain and straw yields of rice by $12 \%$ each of both, even after 18 years of its application. This may be attributed to decreased levels of available zinc in soil under no-Zn treatment and also to solubilization of native as well as applied zinc at higher levels by different crop residues which produce complexing agents and nutrients after microbial decay of crop residue (Prasad et al., 2010; Singh et al., 2012). The mean grain and straw yield of rice increased by $15 \%$ and $16 \%$, respectively, with increasing levels of crop residues incorporation. The highest yield $\left(4.73 \mathrm{t} \mathrm{ha}^{-1}\right)$ was recorded at $100 \%$ crop residue level with application of $10.0 \mathrm{~kg} \mathrm{Zn} \mathrm{ha}^{-1}$. The effects of 
crop residue and $\mathrm{Zn}$ on rice yield were positive. The grain and straw yield of rice increased with increased incorporation of wheat residues from $25 \%$ to $100 \%$. Similar results of increased grain and straw yields of rice due to increased incorporation of crop residues have been reported by Kumar and Kumar (2012). Their study further confirmed that increased availability of nutrients by complexing properties of crop residues was the major contributor to increased grain and straw yields of rice. The literature shows similar results by Prasad et al., (2010) and Rathod et al., (2012) under different agroecologies and cropping systems.

In $\mathrm{T} 1$, the rice grain yield at different levels of starter $\mathrm{Zn}$ application were found at par which indicated that residual effects of $\mathrm{Zn}$ application were very low which increased the yield but not up to significant level. In general, the grain and straw yields at $\mathrm{S} 1$ and $\mathrm{S} 3$ levels and T2 and T3 levels either of $\mathrm{Zn}$ or crop residue incorporation levels were found significant which also indicated that there was an interaction of residual effect of $\mathrm{Zn}$ and incorporation of crop residues on rice grain and straw yields. There was marked increase in yield due to increasing levels of crop residues ( $\mathrm{T} 1$ to $\mathrm{T} 4)$ at all the levels of zinc. The literature shows that improvement in organic carbon and microbial population under higher residue levels might be the reason for augmenting the rice productivity (Pandey, 2012; Das et al., 2012).

\section{Wheat crop}

The grain and straw yields of $36^{\text {th }}$ crop of wheat ranged from 3.12 to 4.13 and 4.87 to $6.44 \mathrm{t} \mathrm{ha}^{-1}$, respectively (Table1). The residual effects of zinc and crop residue levels showed similar trends as observed in rice crop. The wheat yield during initial few years was adversely affected (data not presented here) at higher levels of crop residue incorporation attributing to immobilization of nitrogen and micronutrients by decomposing micro-flora. But during the study period wheat yield increased with increasing levels of crop residues attributing to build-up of organic carbon, nitrogen levels and micronutrients that accelerated faster rate of decomposition of crop residues. Heterotrophic microorganisms use crop residue as a source of organic carbon, nutrient and energy, and degrade the crop residues in soil. The extent of nutrient availability depends not only on type of organic additives but also on the build-up of autochthonous microorganisms. The grain and straw yields increased by $8 \%$ and $7 \%$, respectively, with increasing levels of crop residues from $\mathrm{T} 1$ to $\mathrm{T} 4$.

The wheat yield at $\mathrm{T} 1$ and $\mathrm{T} 2$ levels was at par indicating the starter $\mathrm{Zn}$ level did not influence the yield; however, interaction effects of grain and straw yields were found non-significant.

The highest grain and straw yields were found in the plot receiving $100 \%$ crop residue (T4) incorporation along with $\mathrm{S} 4$. The results obtained in the present investigation are corroborated by those obtained by Prasad et al., (2010), Rathod et al., (2012) and Das et al., (2012).

\section{Micronutrient uptake}

The increase in rice and wheat yields with $\mathrm{Zn}$ application was mainly due to increase in $\mathrm{Zn}$ uptake by rice and wheat (Table 2). Crop residue application increased $\mathrm{Zn}$ uptake by rice and wheat to the tone of $60 \%$ and $57 \%$, respectively.

Crop residues on decay produce a variety of biochemical substances (organic acids, polyphenols, amino acids and polysaccharides), which stimulate the solubility, transport, and availability of $\mathrm{Zn}$. Different levels of crop residues augmented $\mathrm{Cu}$ uptake by rice and wheat by $49 \%$ and $36 \%$, 
respectively. The effects of crop residue and $\mathrm{Zn}$ on $\mathrm{Cu}$ uptake by rice and wheat were statistically significant. Similar results have also been reported by Prasad et al., (2010) in calcareous soils under rice-wheat system.

Incorporation of crop residues increased $\mathrm{Fe}$ uptake by rice and wheat by $19 \%$ and $39 \%$, respectively (Table 3 ). The effects of crop residue on Fe uptake by rice and wheat were significant but effect of $\mathrm{Zn}$ on Fe uptake by rice and wheat was non-significant (Prasad et al., 2010).

Effectiveness of crop residues may be ascribed to their ability after degradation to form water soluble complexes with $\mathrm{Fe}$ and other ions. Perhaps, humic substances and organic acids formed after decomposition of crop residue by microflora may help in the translocation of Fe within the plant.

The most significant influence of crop residues in increasing the solubility and availability of $\mathrm{Fe}$ in the soil is through solubilization of native soil insoluble $\mathrm{Fe}$ and enhanced diffusion and mass flow in the immediate vicinity of plant (O'Connor et al., 1971; Dhaliwal et al., 2012). Crop residues enhanced $\mathrm{Mn}$ uptake by rice and wheat by $18 \%$ and $56 \%$, respectively. Similarly, effect of residual $\mathrm{Zn}$ on $\mathrm{Mn}$ uptake by rice and wheat varied from $21 \%$ and $26 \%$, respectively (Table 3).

\section{Chemical properties of post-harvest soil}

\section{Soil pH}

The soil $\mathrm{pH}$ decreased from 8.16 to 8.14 (Table 4) due to residual $\mathrm{Zn}$ levels over control; however, at all the levels of applied $\mathrm{Zn}$, the $\mathrm{pH}$ was same (8.14). Increasing crop residue levels significantly decreased the $\mathrm{pH}$ from 8.26 to 8.01. Decrease in soil $\mathrm{pH}$ may be attributed to incorporation of crop residue and acid produced by organic matter after incorporation resulting in decrease in $\mathrm{pH}$. Similar results have been reported by Dhaliwal et al., (2012) in the rice-wheat system

\section{Organic Carbon}

Organic carbon (OC) content in soil with continuous incorporation of crop residues either alone or along with residual Zinc application varied from 0.69 to $1.11 \%$ and it increased after eighteenth year of crop residue incorporation from 0.71 to $1.06 \%$ (Table 4). Increasing residual $\mathrm{Zn}$ levels also increased the OC content from 0.83 to $0.90 \%$. Residual effect of $\mathrm{Zn}$ application increased the biomass production resulting in addition of higher quantity of roots and stubbles, which might have built up OC level in soil.

Higher OC content of soil with crop residue incorporation might be attributed to the fact that continuous addition of organic matter through crop residue increased the microbial population which enhanced the decomposition of crop residue resulting in increased OC content. Similar observations have also been reported by Prasad et al., (2010), Nayak et al., (2012) and Adhikari et al., (2012). The interaction effect between $\mathrm{Zn}$ and crop residue level was also significant, where a variation in OC content from 0.69 to $1.11 \%$ was recorded. The results indicated that the effect of crop residue was more apparent when applied along with $\mathrm{Zn}$ as compared to $\mathrm{Zn}$ alone.

Increasing levels of crop residues increased the OC at all levels of residual $\mathrm{Zn}$ (S3 to S4), except at $\mathrm{S} 2$. Increasing levels of $\mathrm{Zn}$ could not increase the OC significantly at any levels of crop residues incorporation; however, significantly increased the OC content in soil at the highest levels of crop residues between no $\mathrm{Zn}(0.98 \%)$ and $10 \mathrm{~kg} \mathrm{Zn} \mathrm{ha}{ }^{-1}$ application $(1.11 \%)$. 
Int.J.Curr.Microbiol.App.Sci (2017) 6(7): 2401-2414

Table.1 Effect of zinc and crop residue (CR) levels on grain and straw yields of rice $\left(35^{\text {th }}\right.$ crop) and wheat (36 ${ }^{\text {th }}$ crop)

\begin{tabular}{|c|c|c|c|c|c|c|c|c|c|c|}
\hline \multirow{3}{*}{$\begin{array}{l}\text { Zn level } \\
\left(\mathrm{kgha}^{-1}\right)\end{array}$} & \multicolumn{5}{|c|}{ Grain yield $\left(\mathrm{t} \mathrm{ha}^{-1}\right)$} & \multicolumn{5}{|c|}{ Straw yield $\left(\mathrm{t} \mathrm{ha}^{-1}\right)$} \\
\hline & \multicolumn{5}{|c|}{ Crop residue level (\% of straw produced) } & \multicolumn{5}{|c|}{ Crop residue level (\% of straw produced) } \\
\hline & $\mathrm{T} 1$ & $\mathrm{~T} 2$ & T3 & $\mathrm{T} 4$ & Mean & $\mathrm{T} 1$ & $\mathrm{~T} 2$ & T3 & $\mathrm{T} 4$ & Mean \\
\hline \multicolumn{11}{|c|}{ Rice $\left(35^{\text {th }}\right.$ crop) } \\
\hline $\mathrm{S} 1$ & 3.63 & 3.83 & 4.05 & 4.10 & 3.90 & 5.07 & 5.38 & 5.67 & 5.78 & 5.48 \\
\hline $\mathrm{S} 2$ & 3.90 & 3.97 & 4.23 & 4.43 & 4.13 & 5.45 & 5.57 & 5.93 & 6.23 & 5.80 \\
\hline $\mathrm{S} 3$ & 3.93 & 4.07 & 4.35 & 4.56 & 4.23 & 5.57 & 5.77 & 6.12 & 6.40 & 5.96 \\
\hline $\mathrm{S} 4$ & 4.08 & 4.23 & 4.43 & 4.73 & 4.37 & 5.72 & 5.97 & 6.22 & 6.60 & 6.13 \\
\hline Mean & 3.89 & 4.03 & 4.27 & 4.46 & & 5.45 & 5.67 & 5.98 & 6.25 & \\
\hline \multirow[t]{3}{*}{$\mathrm{CD}(\mathrm{p}=0.05)$} & $\mathrm{T}$ & & & & 0.29 & & & & & 0.31 \\
\hline & $S$ & & & & 0.18 & & & & & 0.20 \\
\hline & $\mathrm{T} \times \mathrm{S}$ & & & & NS & & & & & NS \\
\hline \multicolumn{11}{|c|}{ Wheat $\left(36^{\text {th }}\right.$ crop $)$} \\
\hline $\mathrm{S} 1$ & 3.12 & 3.22 & 3.46 & 3.76 & 3.39 & 4.87 & 5.03 & 5.40 & 5.87 & 5.29 \\
\hline $\mathrm{S} 2$ & 3.26 & 3.40 & 3.50 & 3.85 & 3.50 & 5.08 & 5.31 & 5.47 & 6.00 & 5.47 \\
\hline $\mathrm{S} 3$ & 3.24 & 3.54 & 3.59 & 3.92 & 3.57 & 5.06 & 5.52 & 5.60 & 6.12 & 5.58 \\
\hline $\mathrm{S} 4$ & 3.26 & 3.57 & 3.67 & 4.13 & 3.66 & 5.08 & 5.56 & 5.73 & 6.44 & 5.70 \\
\hline $\mathrm{S} 1$ & 3.22 & 3.43 & 3.56 & 3.92 & & 5.02 & 5.36 & 5.55 & 6.11 & \\
\hline \multirow[t]{3}{*}{$\mathrm{CD}(\mathrm{p}=0.05)$} & $\mathrm{T}$ & & & & 0.29 & & & & & 0.40 \\
\hline & $\mathrm{S}$ & & & & 0.11 & & & & & 0.24 \\
\hline & $\mathrm{T} \times \mathrm{S}$ & & & & NS & & & & & NS \\
\hline
\end{tabular}

NS: Non-significant

Table.2 Effect of zinc and crop residue levels on $\mathrm{Zn}$ and $\mathrm{Cu}$ uptake $\left(\mathrm{gha}^{-1}\right)$ by rice $\left(35^{\text {th }}\right.$ crop) and wheat $\left(36^{\text {th }}\right.$ crop)

\begin{tabular}{|c|c|c|c|c|c|c|c|c|c|c|c|c|c|c|c|c|c|c|c|c|}
\hline \multirow{3}{*}{$\begin{array}{l}\text { Znlevel } \\
\left(\mathrm{kgha}^{-}\right. \\
\left.{ }^{1}\right)\end{array}$} & \multicolumn{10}{|c|}{ Crop residue level (\% of straw produced) } & \multicolumn{10}{|c|}{ Crop residue level (\% of straw produced) } \\
\hline & \multicolumn{5}{|c|}{ Zn uptake by rice } & \multicolumn{5}{|c|}{ Zn uptake by wheat } & \multicolumn{5}{|c|}{$\mathrm{Cu}$ uptake by rice } & \multicolumn{5}{|c|}{$\mathrm{Cu}$ uptake by wheat } \\
\hline & $\mathrm{T} 1$ & $\mathrm{~T} 2$ & T3 & T4 & Mean & $\mathrm{T} 1$ & $\mathrm{~T} 2$ & T3 & $\mathrm{T} 4$ & Mean & $\mathrm{T} 1$ & $\mathrm{~T} 2$ & $\mathrm{~T} 3$ & T4 & Mean & T1 & $\mathrm{T} 2$ & T3 & $\mathrm{T} 4$ & Mean \\
\hline S1 & 153.4 & 204.5 & 226.6 & 255.9 & 210 & 150.4 & 159.9 & 185.8 & 215 & 177.8 & 36.7 & 44.4 & 49 & 63.5 & 48.4 & 576 & 608 & 720 & 804 & 677 \\
\hline S2 & 182.1 & 216.7 & 247.0 & 288.2 & 234 & 164.1 & 186 & 211.6 & 249 & 202.7 & 40.9 & 48.3 & 49.5 & 64 & 50.7 & 612 & 653 & 739 & 833 & 709 \\
\hline S3 & 205.5 & 249.7 & 253.6 & 314.6 & 256 & 173.4 & 207.3 & 235.3 & 272 & 222.0 & 46.1 & 47.6 & 54.9 & 68.2 & 54.2 & 612 & 713 & 767 & 859 & 738 \\
\hline S4 & 224.2 & 267.9 & 296.2 & 367.1 & 289 & 181.4 & 223.9 & 254.7 & 321 & 245.3 & 50.1 & 52.8 & 54.3 & 63.6 & 55.2 & 640 & 739 & 788 & 917 & 771 \\
\hline Mean & 191 & 235 & 256 & 306 & & 167.3 & 194.3 & 221.9 & 264.3 & & 43.4 & 48.3 & 51.9 & 64.8 & & 610 & 678 & 753 & 853 & \\
\hline $\begin{array}{l}C D \\
(p=0.05)\end{array}$ & $\mathrm{T}$ & 26.7 & & & & $\mathrm{~T}$ & 17.8 & & & & $\mathrm{~T}$ & 4.67 & & & & $\mathrm{~T}$ & 37.3 & & & \\
\hline & $S$ & 17.3 & & & & $S$ & 9.23 & & & & $S$ & 2.89 & & & & $S$ & 21.1 & & & \\
\hline & TxS & NS & & & & $\mathrm{TxS}$ & NS & & & & $\mathrm{TxS}$ & $\mathrm{NS}$ & & & & $\mathrm{TxS}$ & $\mathrm{NS}$ & & & \\
\hline
\end{tabular}

NS: Non-significant 
Table.3 Effect of zinc and crop residue (CR) levels on Fe and Mn uptake (gha $\left.{ }^{-1}\right)$ by rice $\left(35^{\text {th }}\right.$ crop) and wheat $\left(36^{\text {th }}\right.$ crop)

\begin{tabular}{|c|c|c|c|c|c|c|c|c|c|c|c|c|c|c|c|c|c|c|c|c|}
\hline \multirow{3}{*}{$\begin{array}{l}\text { Zn level } \\
\left(\mathrm{kgha}^{-1}\right)\end{array}$} & \multicolumn{10}{|c|}{ Crop residue level (\% of straw produced) } & \multicolumn{10}{|c|}{ Crop residue level (\% of straw produced) } \\
\hline & \multicolumn{5}{|c|}{ Fe uptake by rice } & \multicolumn{5}{|c|}{ Fe uptake by wheat } & \multicolumn{5}{|c|}{ Mn uptake by rice } & \multicolumn{5}{|c|}{ Mn uptake by wheat } \\
\hline & T1 & $\mathrm{T} 2$ & T3 & $\mathrm{T} 4$ & Mean & T1 & $\mathrm{T} 2$ & T3 & $\mathrm{T} 4$ & Mean & T1 & $\mathrm{T} 2$ & T3 & T4 & Mean & T1 & $\mathrm{T} 2$ & T3 & $\mathrm{T} 4$ & Mean \\
\hline $\mathrm{S} 1$ & 719 & 747 & 799 & 810 & 769 & 576 & 608 & 720 & 804 & 677 & 512 & 538 & 532 & 554 & 534 & 395 & 504 & 556 & 654 & 527 \\
\hline $\mathrm{S} 2$ & 749 & 786 & 866 & 929 & 832 & 612 & 653 & 739 & 833 & 709 & 526 & 582 & 594 & 626 & 582 & 448 & 560 & 613 & 685 & 576 \\
\hline S3 & 790 & 823 & 840 & 983 & 859 & 612 & 713 & 767 & 859 & 738 & 551 & 603 & 624 & 676 & 614 & 485 & 596 & 653 & 742 & 619 \\
\hline S4 & 806 & 879 & 919 & 1030 & 909 & 640 & 739 & 788 & 917 & 771 & 596 & 628 & 651 & 718 & 648 & 531 & 624 & 693 & 813 & 665 \\
\hline Mean & 766 & 809 & 856 & 938 & & 610 & 678 & 753 & 853 & & 546 & 588 & 600 & 643 & & 465 & 571 & 629 & 724 & \\
\hline $\begin{array}{l}C D \\
(p=0.05)\end{array}$ & $\begin{array}{c}\mathrm{T} \\
\mathrm{S} \\
\mathrm{TxS} \\
\end{array}$ & & & & $\begin{array}{c}28.7 \\
21.2 \\
\mathrm{NS} \\
\end{array}$ & $\begin{array}{c}\mathrm{T} \\
\mathrm{S} \\
\mathrm{TxS} \\
\end{array}$ & & & & $\begin{array}{c}37.3 \\
21.1 \\
\text { NS } \\
\end{array}$ & $\begin{array}{c}\mathrm{T} \\
\mathrm{S} \\
\mathrm{TxS} \\
\end{array}$ & & & & $\begin{array}{c}41 \\
34 \\
\mathrm{NS} \\
\end{array}$ & $\begin{array}{c}\mathrm{T} \\
\mathrm{S} \\
\mathrm{TxS} \\
\end{array}$ & & & & $\begin{array}{c}31 \\
29 \\
\text { NS } \\
\end{array}$ \\
\hline
\end{tabular}

Table.4 Effect of residual starter $\mathrm{Zn}$ and crop residue incorporation on properties related with soil health in post-harvest soil of wheat (36 ${ }^{\text {th }}$ crop)

\begin{tabular}{|c|c|c|c|c|c|c|c|c|c|c|}
\hline \multirow{3}{*}{$\begin{array}{l}\text { Zn levels } \\
\left(\mathrm{kg} \mathrm{ha}^{-1}\right)\end{array}$} & \multicolumn{10}{|c|}{ Crop residue level (\% of straw produced) } \\
\hline & $\mathrm{T} 1$ & $\mathrm{~T} 2$ & T3 & $\mathrm{T} 4$ & Mean & T1 & $\mathrm{T} 2$ & T3 & T4 & Mean \\
\hline & \multicolumn{10}{|c|}{ Organic Carbon $(\%)$} \\
\hline S1 & 8.30 & 8.21 & 8.11 & 8.01 & 8.16 & 0.69 & 0.77 & 0.88 & 0.98 & 0.83 \\
\hline $\mathrm{S} 2$ & 8.23 & 8.19 & 8.12 & 8.03 & 8.14 & 0.70 & 0.77 & 0.90 & 1.08 & 0.86 \\
\hline S3 & 8.24 & 8.17 & 8.14 & 8.01 & 8.14 & 0.72 & 0.79 & 0.92 & 1.08 & 0.88 \\
\hline S4 & 8.28 & 8.19 & 8.10 & 8.00 & 8.14 & 0.74 & 0.82 & 0.94 & 1.11 & 0.90 \\
\hline Mean & 8.26 & 8.19 & 8.12 & 8.01 & - & 0.71 & 0.79 & 0.91 & 1.06 & - \\
\hline $\mathrm{CD}$ & $\mathrm{T}$ & & 0.06 & & & $\mathrm{CD}$ & $\mathrm{T}$ & & 0.09 & \\
\hline \multirow[t]{2}{*}{$(\mathrm{P}=0.05)$} & $S$ & & 0.01 & & & $(\mathrm{P}=$ & S & & 0.02 & \\
\hline & TX S & & $\mathrm{NS}$ & & & $0.05)$ & TX S & & 0.11 & \\
\hline
\end{tabular}


Table.5 Effect of residual starter $\mathrm{Zn}$ and crop residue incorporation on available major nutrients $\left(\mathrm{kgha}^{-1}\right)$ in post-harvest soil of wheat $\left(36^{\text {th }}\right.$ crop)

\begin{tabular}{|c|c|c|c|c|c|c|c|c|c|c|c|c|c|c|c|}
\hline \multirow{3}{*}{$\begin{array}{l}\text { Zn level } \\
\left(\mathrm{kgha}^{-1}\right)\end{array}$} & \multicolumn{15}{|c|}{ Crop residue level (\% of straw produced) } \\
\hline & T1 & $\mathrm{T} 2$ & $\mathrm{~T} 3$ & $\mathrm{~T} 4$ & Mean & T1 & $\mathrm{T} 2$ & T3 & $\mathrm{T} 4$ & Mean & T1 & $\mathrm{T} 2$ & T3 & $\mathrm{T} 4$ & Mean \\
\hline & \multicolumn{5}{|c|}{ Nitrogen } & \multicolumn{5}{|c|}{$\mathrm{P}_{2} \mathrm{O}_{5}$} & \multicolumn{5}{|c|}{$\mathrm{K}_{2} \mathrm{O}$} \\
\hline S1 & 220 & 229 & 240 & 249 & 234 & 19.23 & 24.60 & 29.60 & 33.83 & 26.82 & 131 & 141 & 152 & 159 & 145 \\
\hline $\mathrm{S} 2$ & 222 & 233 & 243 & 251 & 237 & 19.53 & 25.03 & 30.90 & 33.87 & 27.33 & 133 & 143 & 154 & 161 & 148 \\
\hline S3 & 225 & 235 & 244 & 253 & 239 & 20.63 & 27.30 & 31.53 & 34.47 & 28.48 & 136 & 145 & 155 & 163 & 150 \\
\hline S4 & 226 & 235 & 246 & 255 & 240 & 23.07 & 27.87 & 32.10 & 34.83 & 29.47 & 138 & 147 & 156 & 165 & 151 \\
\hline Mean & 224 & 233 & 243 & 252 & - & 20.62 & 26.20 & 31.03 & 34.25 & - & 134 & 144 & 154 & 162 & - \\
\hline $\mathrm{CD}(\mathrm{P}=0.05)$ & $\mathrm{T}$ & & & & 3 & $\mathrm{~T}$ & & & & 1.45 & $\mathrm{~T}$ & & & & 2 \\
\hline & $\mathrm{S}$ & & & & 1 & S & & & & 0.72 & $\mathrm{~S}$ & & & & 1 \\
\hline & $\mathrm{T} \times \mathrm{S}$ & & & & 3 & $\mathrm{~T} \times \mathrm{S}$ & & & & 1.45 & $\mathrm{~T} \times \mathrm{S}$ & & & & 2 \\
\hline
\end{tabular}

Table.6 Effect of zinc and crop residue incorporation on available micronutrient cautions $\left(\mathrm{mgkg}^{-1}\right)$ in Post-harvest soil of wheat $\left(36^{\text {th }}\right)$ under rice-wheat cropping system

\begin{tabular}{|c|c|c|c|c|c|c|c|c|c|c|c|c|c|c|c|c|c|c|c|c|}
\hline \multirow{3}{*}{$\begin{array}{l}\mathrm{Zn} \\
\text { level } \\
\left(\mathrm{kgha}^{-}\right. \\
\left.{ }^{1}\right)\end{array}$} & \multicolumn{20}{|c|}{ Crop residue level (\% of straw produced) } \\
\hline & \multicolumn{5}{|c|}{ Available Zn } & \multicolumn{5}{|c|}{ Available $\mathrm{Cu}$} & \multicolumn{5}{|c|}{ Available Fe } & \multicolumn{5}{|c|}{ Available Mn } \\
\hline & T1 & $\mathrm{T} 2$ & T3 & $\mathrm{T} 4$ & Mean & T1 & $\mathrm{T} 2$ & T3 & $\mathrm{T} 4$ & Mean & $\mathrm{T} 1$ & $\mathrm{~T} 2$ & $\mathrm{~T} 3$ & $\mathrm{~T} 4$ & Mean & $\mathrm{T} 1$ & $\mathrm{~T} 2$ & T3 & $\mathrm{T} 4$ & Mean \\
\hline S1 & 0.38 & 0.43 & 0.52 & 0.78 & 0.53 & 3.09 & 3.25 & 3.51 & 3.73 & 3.40 & 16.33 & 16.93 & 18.30 & 19.0 & 17.64 & 4.30 & 4.39 & 4.72 & 4.89 & 4.58 \\
\hline S2 & 0.40 & 0.42 & 0.58 & 0.91 & 0.58 & 3.11 & 3.23 & 3.47 & 3.67 & 3.37 & 16.27 & 16.57 & 18.37 & 19.23 & 17.61 & 4.29 & 4.42 & 4.70 & 4.85 & 4.57 \\
\hline S3 & 0.41 & 0.44 & 0.68 & 1.05 & 0.65 & 3.09 & 3.18 & 3.46 & 3.63 & 3.34 & 15.87 & 16.33 & 18.07 & 18.93 & 17.30 & 4.29 & 4.35 & 4.68 & 4.91 & 4.56 \\
\hline S4 & 0.42 & 0.44 & 0.95 & 1.21 & 0.76 & 3.11 & 3.16 & 3.40 & 3.58 & 3.31 & 15.40 & 16.17 & 17.90 & 18.57 & 17.01 & 4.32 & 4.36 & 4.69 & 4.80 & 4.54 \\
\hline Mean & 0.40 & 0.43 & 0.68 & 0.99 & & 3.10 & 3.21 & 3.46 & 3.65 & & 15.97 & 16.50 & 18.16 & 18.93 & & 4.30 & 4.38 & 4.70 & 4.86 & \\
\hline $\begin{array}{l}C D \\
(p= \\
0.05)\end{array}$ & $\begin{array}{c}\mathrm{T} \\
\mathrm{S} \\
\mathrm{Tx} \\
\mathrm{S}\end{array}$ & & & & $\begin{array}{l}0.05 \\
0.04 \\
0.08\end{array}$ & $\begin{array}{c}\mathrm{T} \\
\mathrm{S} \\
\mathrm{TxS}\end{array}$ & & & & $\begin{array}{l}0.05 \\
0.01 \\
0.04\end{array}$ & $\begin{array}{c}\mathrm{T} \\
\mathrm{S} \\
\mathrm{Tx} \mathrm{S}\end{array}$ & & & & $\begin{array}{l}0.26 \\
0.15 \\
0.15\end{array}$ & $\begin{array}{c}\mathrm{T} \\
\mathrm{S} \\
\mathrm{Tx} \mathrm{S}\end{array}$ & & & & $\begin{array}{l}0.07 \\
0.03 \\
0.05\end{array}$ \\
\hline
\end{tabular}




\section{Available macro-nutrients}

\section{Available nitrogen}

Data illustrated in table 5 indicated that levels of crop residues, residual starter zinc and their interaction significantly influenced available nitrogen content of soil. Significant buildup of available $\mathrm{N}$ was recorded with graded levels of zinc and also with residue incorporation as presented in table 5. Application of crop residue and residual starter $\mathrm{Zn}$ increased available $\mathrm{N}$ content in soil by $13 \%$ and $3 \%$, respectively. This increase was higher over absolute control and initial value, which indicates the buildup of available $\mathrm{N}$ in soil. Kumar et al., (2010) and Kumari and Singh (2012) also reported the positive effect of residues on available $\mathrm{N}$ status of soil in ricewheat cropping system.

\section{Available phosphate and potash}

A critical analysis of data on available $\mathrm{P}_{2} \mathrm{O}_{5}$ and $\mathrm{K}_{2} \mathrm{O}$ as given in table 5 revealed that there was positive effect of residual starter $\mathrm{Zn}$, crop residue levels and their interactions on these two soil nutrients. The overall variation in available $\mathrm{P}_{2} \mathrm{O}_{5}$ was observed up to $81 \%$, whereas available $\mathrm{K}_{2} \mathrm{O}$ varied up to $26 \%$. The increase in available $\mathrm{P}_{2} \mathrm{O}_{5}$ was found positively influenced by $\mathrm{Zn}$ levels ( $\mathrm{S} 1$ to $\mathrm{S} 4$ ) by $10 \%$ and due to crop residue levels by $66 \%$. Similarly, increasing levels of $\mathrm{Zn}$ linearly increased the available $\mathrm{K}_{2} \mathrm{O}$ content in soil by $4 \%$. The positive variation in available $\mathrm{K}_{2} \mathrm{O}(21 \%)$ was obtained with increasing levels of crop residue. Addition of organic matter, in general, increased nonsymbiotic nitrogen fixing bacteria (Kumari and Singh, 2012). Heterotrophic microorganisms act on organic materials, degrade in soil and consequently release these nutrients in soil. The extent of availability of nutrients depends not only on the type of organic additives but also on the buildup of microorganisms (Prasad et al., 2012). Enhanced microbial mineralization might have resulted in increase of available $\mathrm{P}_{2} \mathrm{O}_{5}$ and $\mathrm{K}_{2} \mathrm{O}$ in the present investigation. The increase in phosphatase activity due to crop residue or organic sources incorporation and increase in available $\mathrm{P}_{2} \mathrm{O}_{5}$ and $\mathrm{K}_{2} \mathrm{O}$ in soil has also been reported by earlier workers (Singh et al., 2012; Sanjay et al., 2011). They further described that with lapses of time, the amount of $\mathrm{K}$ mineralized, increased significantly and raised the available $K$ pool in soil due to release of more organically bound $\mathrm{K}$ in course of decomposition of organic waste.

\section{Available micronutrients}

\section{Available Zn}

The residual effect of starter $\mathrm{Zn}$ and crop residue incorporation on available $\mathrm{Zn}$ in soil after harvest of $36^{\text {th }}$ crop of wheat under ricewheat cropping system is elaborated in table 6. Available $\mathrm{Zn}$ in post-harvest soil varied from 0.38 to $1.21 \mathrm{mg} \mathrm{kg}^{-1}$ due to different treatment combinations. The data revealed that increasing $\mathrm{Zn}$ application levels ( $\mathrm{S} 1$ to S4) increased the available $\mathrm{Zn}$ status of soil by $43 \%$, although the value was below the critical level of $0.78 \mathrm{mg} \mathrm{kg}^{-1}$ as reported by Sakal and Singh (1979) for such calcareous soils in the region. The increases in available $\mathrm{Zn}$ due to crop residue incorporation were higher with increasing levels by $147 \%$; however, available $\mathrm{Zn}$ at $\mathrm{T} 1\left(0.40 \mathrm{mg} \mathrm{kg}^{-1}\right)$ and at T2 $\left(0.43 \mathrm{mg} \mathrm{kg}^{-1}\right)$ were significantly at par. The buildup of available $\mathrm{Zn}$ due to crop residues incorporation has also been reported earlier (Singh et al., 2010; Walia et al., 2010; Tripathi and Kumar, 2013). This buildup has been reported due to addition of $\mathrm{Zn}$ through crop residue and/or exploitation of native $\mathrm{Zn}$ by chelation through decomposition product of crop residues. Organic matter was also found to increase the efficiency of applied Zn as inorganic fertilizer (Walia et al., 2010). 
The interaction effect between $\mathrm{Zn}$ and crop residue levels was significant which suggested that not only the addition of $\mathrm{Zn}$ through $\mathrm{ZnSO}_{4}$ or crop residue incorporation enhanced the buildup of available $\mathrm{Zn}$ but also the solubilization of native $\mathrm{Zn}$ by the organic acids produced during the decomposition of crop residue was responsible for buildup of available $\mathrm{Zn}$ in post-harvest soils.

Crop residue incorporation alone applied @ 100\% straw produced for 18 complete years (data not presented here) was able to raise the available $\mathrm{Zn}$ status of soil up to the extent of $0.78 \mathrm{mg} \mathrm{kg}{ }^{-1}$ which is equivalent to the critical level of zinc. The crop residues applied to the extent of even 50 per cent of straw produced along with the starter dose of $\mathrm{Zn}$ at least $10 \mathrm{~kg} \mathrm{Zn} \mathrm{ha}{ }^{-1}$ or in the case of $100 \%$ crop residue along with any of the four given treatments of $\mathrm{Zn}$ increased the available $\mathrm{Zn}$ content in soil above critical level $(0.78$ $\mathrm{mg} \mathrm{kg}{ }^{-1}$ ).

\section{Available Fe}

It was observed that increasing levels of $\mathrm{Zn}$ significantly decreased the available $\mathrm{Fe}$ content in soil by $4 \%$, however, available $\mathrm{Fe}$ at $\mathrm{S} 1\left(17.64 \mathrm{mg} \mathrm{kg}^{-1}\right)$ and $\mathrm{S} 2\left(17.61 \mathrm{mg} \mathrm{kg}^{-1}\right)$ were significantly at par (Table 6). The antagonistic effect of $\mathrm{Zn}$ on $\mathrm{Fe}$ has already been reported by earlier workers (Prasad et al., 2009; Singh et al., 2012; Prasad et al., 2012). Increasing levels of crop residue incorporation significantly increased the available $\mathrm{Fe}$ content in soil and this increase was more pronounced at the highest level, i.e. T4 by $19 \%$.

This increase in available Fe may be due to solubilization of native $\mathrm{Fe}$ by organic acids produced from crop residue. The interaction effect was also found significant which indicated that at zero level of crop residue, the decrease in the available Fe was sharp due to
$\mathrm{Zn}$ application. Similarly, at zero level of $\mathrm{Zn}$ application, the increase in available Fe was more marked with increasing levels of crop residue.

\section{Available $\mathbf{C u}$}

The available $\mathrm{Cu}$ content in post-harvest soil $\left(36^{\text {th }}\right.$ crop) due to different treatment combinations of residual effect of starter $\mathrm{Zn}$ and crop residues varied from 3.09 to $3.73 \mathrm{mg}$ $\mathrm{kg}^{-1}$ (Table 6). Residual effect of starter $\mathrm{Zn}$ reduced the available $\mathrm{Cu}$ content by $3 \%$, which might be due to ionic competition with Zn. Similar observation was also recorded by Sakal et al., (1996). Increasing levels of crop residue enhanced the available $\mathrm{Cu}$ by $18 \%$, which might be due to addition of $\mathrm{Cu}$ through crop residues. Buildup of OC in soil increased the availability of $\mathrm{Cu}$ due to chelation properties of organic matter. The interaction effect was also found significant. This suggested that different levels of crop residues react differently at different levels of $\mathrm{Zn}$ and vice-versa. There was more buildup of available $\mathrm{Cu}$ in absence of $\mathrm{Zn}$ application. The reduction in available $\mathrm{Cu}$ was more due to $\mathrm{Zn}$ application at higher level of crop residue incorporation. Such result was due to the fact that at higher crop residue level the buildup of $\mathrm{Zn}$ was also more resulting in increased competition between $\mathrm{Cu}$ and $\mathrm{Zn}$. The antagonistic effect of $\mathrm{Zn}$ on $\mathrm{Cu}$ has also been reported by Sakal et al., (1985); Prasad et al., (2009) and Sharma et al., (2013).

\section{Available Mn}

The effect of $\mathrm{Zn}$ and crop residue on available Mn content of post-harvest soil (after $36^{\text {th }}$ crop) was very much similar to those on $\mathrm{Fe}$ and $\mathrm{Cu}$ (Table 6). Increasing levels of crop residue incorporation significantly increased the available $\mathrm{Mn}(13 \%)$, while $\mathrm{Zn}$ application decreased the available Mn (1\%). The overall variation in available $\mathrm{Mn}$ in soil ranged from 
4.29 to $4.91 \mathrm{mg} \mathrm{kg}^{-1}$. The depressing effect of $\mathrm{Zn}$ on the availability of $\mathrm{Mn}$ has also been reported by Sharma and Bapat (2000). The interaction effect was found significant, which suggested that different levels of crop residues react differently at different levels of Zn. Singh et al., (2012) also reported significant effect on micronutrient status in soil after combined use of NPK and Zn with organic manure and it enhances the nutrient uptake by crops. Crop residues incorporation can improve micronutrients availability.

In conclusion, our results after superimposing of treatments on a 18-year ricewheat rotation trial reported in this paper demonstrate significant effects of crop residues incorporation and $\mathrm{Zn}$ application on soil macro-nutrients, micro-nutrients, their availability, soil chemical productivities and crop productivity. Maximum rice and wheat yields were obtained at $100 \%$ crop residues incorporation along with $10 \mathrm{~kg}$ residual application of starter $\mathrm{Zn} \mathrm{ha}{ }^{-1}$. The increased yields of rice and wheat were also attributed to higher micronutrients uptake at higher levels of residue incorporation and $\mathrm{Zn}$ application. The crop residue incorporation also enhanced the soil health by soil chemical properties as $\mathrm{pH}$ and organic carbon and $\mathrm{Zn}$ addition further improved the availability of both macronutrients (NPK) and micronutrient, $\mathrm{Zn}$. But with increased levels of $\mathrm{Zn}$ application, the $\mathrm{Fe}, \mathrm{Cu}$ and $\mathrm{Mn}$ availability decreased in the soil. The crop residues incorporation can augment micronutrient availability in the calcareous soils. Our results highlight the research need to understand the mechanisms and availability of macro- and micronutrients under different crop residue incorporation levels and micronutrient application in rice-wheat cropping system, which is crucial for developing innovative nutrient application technologies and associated agronomy for higher yield potential.

\section{References}

Adhikari, K.R., Chen, Z.S., Shah, S.C., Dahal, K.R. 2012. Soil organic carbon sequestration as affected by tillage, crop residue and nitrogen application in ricewheat rotation system. Paddy Water Environment, 10(2): 95-102.

Das, T., Ram, S., Sirari, P. 2012. Effect of long term application of inorganic fertilizers and manure on yields, nutrients uptake and grain quality of wheat under rice-wheat cropping system on a Mollisol. Pantnagar J. Research, 10(2): 174-180.

Dhaliwal, S.S., Sadana, U.S., Walia, S.S., Sidhu, S.S. 2012. Long-term effects of manures and fertilizers on chemical fractions of $\mathrm{Fe}$ and $\mathrm{Mn}$ and their uptake under rice-wheat cropping system in North-West India. Int. J. Agril. Science, 8 (1): 98-107.

Jackson, M.L. 1978. Soil Chemical Analysis. Prentice Hall of India [P] Ltd., New Delhi.

Koushal, S., Sharma, A.K., Singh, A. 2011. Yield performance, economics and soil fertility through direct and residual effects of organic and inorganic sources of nitrogen as substitute to chemical fertilizer in rice-wheat cropping system. Res. J. Agril. Sci., 43(3): 189-192.

Kumar, A., Kumar, N. 2012. Crop residue management for sustainable crop production and soil health in rice-wheat cropping system. Research on Crops, 13(2): 412-417.

Kumar, R., Kumar, S., Singh, D.K., Singh, A. 2010. Response of barley to copper fertilization in acid soil of Doon valley. Indian J. Fertilizer, 6(7): 66.

Lathwal, O.P., Goyal, S.P., Chauhan R.S. 2010.Introduction of summer mungbean in rice - wheat cropping system in Haryana. Indian Journal of Fertilizer, 6(2): 37-39. 
Lindsay, W.L., Norvell, W.A. 1978. Development of DTPA soil test for zinc, iron, manganese and copper. Soil Science Soc. American Journal, 42: 421-428.

Nayak, A.K., Gangwar, B., Shukla, A.K., Mazumdar, S.P., Kumar, A., Raja, R., Kumar, A., Kumar, V., Rai, P.K., Mohan, U. 2012. Long-term effect of different integrated nutrient management on soil organic carbon and its fractions and sustainability of ricewheat system in Indo Gangetic Plains of India. Field Crops Research, 127: 129139.

O’Connor, G.A., Lindsay, W.L., Olsen, S.R. 1971. Diffusion of iron and Fe-chelates in soil. Soil Science Soc. American Proceeding, 35: 407-410.

Pandey, A. 2012. Long term effect of organic and inorganic fertilizers on the distribution and transformation of $\mathrm{S}, \mathrm{Zn}$ and Boron in calcareous soil. Ph.D. Thesis, Department of Soil Science, RAU, Pusa, India. pp: 200.

Prasad,R.K., Kumar, V. 2011. Mineralization of carbon and nitrogen in zinc-treated rice field in calcareous soil. Agropedology, 21(1): 23-27.

Prasad, R.K., Kumar, V., Mandal, K., Kumar, R. 2009. Long term application of zinc and crop residues on yield and uptake of micronutrients in transplanted rice under rice-wheat cropping system in calciorthents. Environ. Ecology, 27 (3A): 1440-1443.

Prasad, R.K., Kumar, V., Prasad, B., Singh, A.K. 2010. Long-term effect of crop residues and zinc fertilizer on crop yield nutrient uptake and fertility build up under rice-wheat cropping system in calciorthents. J. Indian Society Soil Sciences, 58: 205-211.

Kumari, R., Singh, A.P. 2012. Crop yield and nutrient uptake as affected by different levels of zinc fertilizer and crop residue incorporation under rice-wheat system in calciorthents. Environ. Ecology, 30(4): 1336-1342.

Rathod, D.D., Meena, N.C., Patel K.P. 2012. Evaluation of different zinc-enriched organics as source of zinc under wheatmaize (fodder) cropping sequence on zinc deficient typichaplustepts. J. Indian Society for Soil Sciences, 60(1): 50-55.

Sakal, R., Singh, A.P. 1979. Zinc hunger in Kharif crop grown on calcareous soil of North Bihar. Indian Farming, 28(2): 35.

Sakal, R., Singh, A.P., Singh, B.P., Sinha, R.B., Jha, S.N., Singh, S.P. 1985. Distribution of available micronutrient cations in calcareous soils as related to certain soil properties. J. Indian Society Soil Sciences, 33: 672-675.

Sakal, R., Singh, A.P., Sinha, R.B., Bhogal, N.S. 1996. Twenty five years of research on micro and secondary nutrients in soil and crops of Bihar. Research Bulletin, Department of Soil Science, Faculty of Agriculture, R.A.U., Pusa, Samastipur (Bihar).

Sharma, B.L., Bapat, P.N. 2000. Levels of micronutrient cations in various plant parts of wheat as influenced by zinc and phosphorus application. J. Indian Soc. Soil Sciences, 48: 130-134.

Sharma, Y. K., Singh, H., Mandal, N. 2013. Effect of nitrogen and copper levels on yield anduptake of nutrients by wheat crop. Annals of Plant Soil Research, 15 (1): 43-46.

Singh, A.P., Ram, N., Singh, V. 2010. Impact of 3-decades of fertilizers use on the availability of DTPA-extractable micronutrients and its comparison with other extractants on a Mollisol of North India. Environ. Ecology, 28(1B): 523529.

Singh, J.P., Kaur, J., Mehta, D.S., Narwal, R.P. 2012. Long-term effects of nutrient management on soil health and crop 
productivity under rice-wheat cropping system. Indian J. Fertilizer, 8(8): 28-48.

Subbiah, B.V., Asija, G.L. 1956. A rapid procedure for the determination of available nitrogen in soils. Current Science, 25: 259-260.

Tripathi, B.N., Kumar, R. 2013. Effect of zinc and sulphur levels on rice in partially reclaimed typic natrustalls sodic soil. Annals of Plant Soil Res., 15(1): 27-30.

Walia, M.K., Walia, S.S., Dhaliwal, S.S. 2010. Long-term effect of integrated nutrient management on properties of typicustochrept after 23 cycles of an irrigated rice (Oryza sativa L.)-wheat
(Triticum aestivum L.) system. $J$. Sustainable Agriculture, 34(7): 724743.

Watanabe, F.S. Olsen, S.R.1965. Test of an ascorbic acid method for determining $\mathrm{P}_{2} \mathrm{O}_{5}$ in water and $\mathrm{NaHCO}_{3}$ extracts from soils. Soil Science Soc. American Proceedings, 29:677-678.

Yadav, M.P., Aslam, M., Kushwaha, S.P. 2005. Effect of integrated nutrient management on rice (oryza sativa) wheat (Triticum aestivum) cropping system in central plains of Uttar Pradesh. Indian J. Agronomy, 50(2): 8993.

\section{How to cite this article:}

Kamini Kumari, J. Prasad, Ishwar Singh Solanki and Ravish Choudhary. 2017. Long-term Effect of Residual Zinc and Crop Residues Incorporation on Soil Health and Crop Productivity under Calcareous Soils of Rice-Wheat System in India. Int.J.Curr.Microbiol.App.Sci. 6(7): 2401-2414. doi: https://doi.org/10.20546/ijcmas.2017.607.342 